\title{
PENGARUH MODEL PEMBELAJARAN TIPE PAIR CHECKS \\ DIPADUKAN DENGAN EKSPERIMEN TERHADAP MOTIVASI \\ DAN HASIL BELAJAR KIMIA SISWA KELAS X MADRASAH
}

ALIYAH AL-ISHAHUL ITTIHAD.

\section{Samsul Hadi', Lukman Taufiq', Raehanah'}

${ }^{1}$ Tadris Kimia, FTK UIN Mataram, Mataram. Email:

raehanah@uinmataram.ac.id

\section{ABSTRAK}

Tujuan penelitian ini adalah untuk mengetahui pengaruh penggunaan model pembelajaran cooperative learning tipe pair checks dipadukan dengan eksperimen terhadap motivasi dan hasil belajar. Jenis penelitian ini adalah penelitian kuantitatif dengan menggunakan pendekatan quasi eksperimen dan dilaksanakan dari bulan Februari Maret 2019. Populasi penelitian ini adalah semua siswa kelas X IPA MA AlIshlahul Ittihad Jabon Tentan Tahun Ajaran 2018/2019. Sampel diperoleh dengan tehnik sampel random sampling. Kelas A dijadikan sebagai kelas eksperimen yang diajarkan dengan model pembelajaran cooperative, sedangkan kelas B dijadikan sebagai kelas kontrol yang diajarkan dengan model pembelajaran konvensional. Data diperoleh dengan metode angket untuk motivasi belajar dan tes untuk hasil belajar. Hipotesis diuji menggunakan Kruskall Wallis dan Mann Whitney Test. Dari hasil analisis data disimpulkan: 1) Nilai sig 0,001 < 0,005 artinya ada pengaruh penggunaan model pembelajaran cooperative learning tipe pair checks dipadukan dengan eksperimen terhadap motivasi dan hasil belajar secara multivariate, 2) nilai sig 0,039 < 0,05 artinya ada pengaruh penggunaan model pembelajaran cooperative learning tipe pair checks dipadukan dengan eksperimen terhadap motivasi belajar, 3) nilai sig 0,000 $<0,005$ artinya ada pengaruh penggunaan model pembelajaran cooperative learning tipe pair checks dipadukan dengan eksperimen terhadap hasil belajar.

KATA KUNCI Model Pembelajaran Cooperative Learning Tipe Pair Checks, Motivasi, Hasil Belajar. 


\section{PENDAHULUAN}

Keberhasilan atau kegagalan suatu pendidikan dilihat dari bagaimana cara pendidik mengaplikasikan ilmunya kepada peserta didik di dalam proses belajar mengajar. Oleh karena itu guru dituntut untuk berpikir kreatif dalam melaksanakan kegiatan belajar-mengajar. Dalam pelaksanaan belajar mengajar guru dapat memilih dan menentukan pendekatan dan metode yang sesuai dengan kemampuannya. Setiap guru mempunyai cara tersendiri dalam melaksanakan tugasnya sebagai pengajar. Sehingga dengan demikian akan tercipta situasi belajar yang efektif dan efisien sesuai dengan pokok pembahasan pada mata pelajaran kimia.

Ilmu kimia merupakan ilmu yang diperoleh dan dikembangkan berdasarkan eksperimen yang mencari jawaban atas pertanyaan apa, mengapa dan bagaimana gejala-gejala alam; khususnya yang berkaitan dengan komposisi, struktur dan sifat, transformasi, dinamika, dan energetika zat. Kimia dianggap sebagai ilmu yang kurang menarik dan sulit karena kimia erat hubungannya dengan ide-ide atau konsep-konsep abstrak dan perbendaharaan kata yang khusus, sehingga mempelajari kimia seperti mempelajari bahasa yang baru. Oleh karena itu, dalam pembelajaran kimia perlu dilakukan suatu praktikum.

Proses pembelajaran kimia mestinya menekankan pada pemberian pengalaman langsung (praktikum) kepada siswa sehingga siswa memperoleh pemahaman mendalam tentang materi yang diajarkan. Hal ini karena ilmu kimia sangat berhubungan dengan kehidupan sehari-hari. 
Pembelajaran kimia di sekolah seharusnya melibatkan aspek sikap, proses, produk, dan aplikasi. Dengan demikian siswa dapat mengalami proses pembelajaran secara utuh, memahami fenomena alam melalui kegiatan pemecahan masalah, metode ilmiah, dan meniru kerja ilmuan dalam menemukan fakta baru. Kecendrungan pembelajaran kimia saat ini hanya menghafalkan konsep, teori dan hukum, serta berorientasi pada hapalan. Akibatnya, sikap, proses, dan aplikasi tidak tersentuh dalam pembelajaran. Pengalaman pembelajaran di kelas tidak utuh dan tidak berorientasi tercapainya standar kompetensi dan kompetensi dasar.

Begitu juga dengan yang terjadi di Madrasah Aliyah Al-Ishlahul Ittihad, proses belajar-mengajar kimia di Madrasah tersebut suasana kelas cendrung teacher centred, guru hanya menyampaikan kimia sebagai produk dan siswa menghapal faktual. Fakta dilapangan menunjukkan bahwa siswa cenderung malas berpikir secara mandiri. Berdasarkan hasil observasi dan wawancara diperoleh kesimpulan bahwa rendahnya hasil belajar siswa diduga disebabkan karena: 1) rendahnya pemahaman siswa dalam menerima pelajaran yang diberikan oleh guru, sehingga sulit menjawab pertanyaan-pertanyaan; 2) belum terjadi suasana aktif dalam diskusi; dan 3) kurangnya keterlibatan siswa secara langsung dalam proses pembelajaran. Beberapa siswa menjawab pertanyaan dengan ragu-ragu, keberanian siswa untuk mengajukan pendapat dan bertanya juga kurang.

Guru juga sering mengajar dengan metode ceramah. Karena baginya metode ceramah merupakan metode yang 
sangat simple dan mudah diterapkan dalam proses pembelajaran, dapat mengontrol keadaan kelas. Selain guru sering menggunakan metode ceramah hasil belajar siswa juga dipengaruhi oleh kurangnya fasilitas laboratorium yang menyebabkan guru jarang melakukan kegiatan praktikum. Karena jarangnya kegiatan praktikum maka guru hanya mengevaluasi pada aspek kognitif saja.

Permasalahan yang terjadi di Madrasah Aliyah AlIshlahul Ittihad Jabon Tentan bisa dilihat implikasinya dengan masih rendahnya hasil belajar siswa. Seperti diketahui, motivasi belajar pada siswa tidak sama kuatnya, ada siswa yang motivasinya bersifat intrinsik dimana kemauan belajarnya lebih kuat dan tidak tergantung faktor diluar dirinya. Sebaliknya dengan siswa yang motivasi belajarnya bersifat ekstrinsik, kemauan untuk belajar sangat tergantung pada kondisi diluar dirinya. Namun demikian, dalam kenyataannya motivasi ekstrinsik inilah yang banyak terjadi, terutama pada anak-anak dan remaja dalam proses belajar. Motivasi merupakan penggerak, maupun dorongan yang dapat memicu timbulnya rasa semangat dan juga mampu merubah tingkah laku manusia atau individu untuk menuju pada hal yang lebih baik untuk dirinya sendiri.

Melihat kondisi tersebut proses pembelajaran di MA Al-Ishlahul Ittihad tergolong belum maksimal apabila kita melihatnya dari hasil belajar yang dimiliki siswa. Proses pembelajaran akan berhasil manakala siswa mempunyai motivasi dalam belajar. Oleh karena itu, guru perlu menumbuhkan motivasi belajar siswa, sehingga untuk mengatasi permasalahan tersebut perlu adanya inovasi 
metode, strategi dan model pembelajaran yang dapat meningkatkan motivasi siswa dalam belajar sehingga meningkatkan hasil belajarnya. Untuk meningkatkan hasil belajarnya dibutuhkan suatu pembelajaran yang efektif. Salah satu caranya yaitu menggunakan model pembelajaran cooperative learning. Model cooperative learning yaitu suatu model pembelajaran dengan menggunakan sistem pengelompokan atau tim kecil dengan sejumlah siswa yang mempunyai tingkat kemampuan yang berbeda-beda (heterogen).

Salah satu model pembelajaran kooperatif yang efektif dan menekankan partisipatif siswa adalah model pembelajaran pair checks. Medel ini adalah model pembelajaran dengan metode belajar dengan bekerja berpasangan sebagai pelatih dan partner. Secara umum, sintak pembelajaran pair checks adalah: 1). Bekerja berpasangan; 2). Pembagian peran partner dan pelatih; 3). Pelatih memberi soal, partner menjawab; 4). Pengecekan jawaban; 5). Bertukar peran; 5). Penyimpulan; 6). Evaluasi; dan 7).Refleksi. Metode pair checks memiliki kelebihankelebihannya tersendiri, antara lain: 1). Meningkatkan kerja sama antar siswa; 2). Peer tutoring; 3). Meningkatkan pemahaman antar konsep/dan atau proses pembelajaran; 4). Melatih siswa berkomunikasi dengan baik dengan teman sebangkunya (Huda, 2017).

Penelitian yang sudah dilakukan sebelumnya menunjukkan metode cooperative learning tipe pair checks berpengaruh positif terhadap motivasi dan hasil belajar siswa. Contohnya penelitian yang dilakukan oleh Fandi 
Ahmad yang menyatakan bahwa metode cooperative learning tipe pair checks berpengaruh positif terhadap motivasi dan hasil belajar siswa (Ahmad, 2016). Begitu juga dengan penelitian Islamiah, dkk (2016) serta Edy Setiyo Utomol dan Fatchiyah Rahman (2016) menunjukkan metode cooperative learning tipe pair checks berpengaruh positif terhadap hasil belajar siswa.

\section{METODE PENELITIAN}

Penelitian ini adalah penelitian kuantitatif. Pendekatan penelitian yang digunakan adalah pendekatan quasi eksperimen. Penelitian ini dilakukan pada bulan Januari-Februari dengan jumlah populasi sebanyak 32. Kelas eksperimen dan kelas kontrol terdiri dari 16 siswa. Desain penelitian menggunakan metode posttest-only control group design untuk hasil belajar dan pretest posttest control group design untuk motivasi belajar. Instrumen penelitian ini adalah angket untuk motivasi belajar dan tes obyektif untuk hasil belajar. Analisis data dibagi menjadi dua yaitu: pertama uji prasyarat yang terdiri dari dari uji normalitas, uji general linear model, dan uji kesamaan matriks kovarians. Kedua uji hipotesis yang terdiri dari kruskal wallis dan mannwhitney test. Analisis menggunakan aplikasi SPSS. 


\section{HASIL DAN PEMBAHASAN}

\section{Hasil Penelitian}

Berikut ini adalah data motivasi dan hasil belajar peserta didik siswa kelas X MA Al-Ishlahul Ittihad Jabon Tentan tahun ajaran 2018/2019.

\section{a. Data Motivasi}

Table 1 Deskripsi Nilai Motivasi Belajar Kimia

\begin{tabular}{|l|r|r|}
\hline \multirow{2}{*}{\multicolumn{1}{|c|}{ Aspek }} & \multicolumn{2}{|c|}{ Nilai } \\
\cline { 2 - 3 } & \multicolumn{1}{|c|}{ Kelas Eksperimen } & \multicolumn{1}{c|}{ Kelas Kontrol } \\
\hline Nilai maksimum & 85 & 83 \\
\hline Nilai minimum & 69 & 55 \\
\hline Nilai rata-rata & 76,81 & 70,12 \\
\hline Jumlah sampel & 16 & 16 \\
\hline Standar deviasi & 5,34 & 4,52 \\
\hline
\end{tabular}

b. Data Hasil Belajar

Table 2 Deskripsi Nilai Hasil Belajar Kimia

\begin{tabular}{|c|c|c|}
\hline \multirow{2}{*}{ Aspek } & \multicolumn{2}{|c|}{ Nilai } \\
\hline & Kelas Eksperimen & Kelas Kontrol \\
\hline Nilai maksimum & 80 & 70 \\
\hline Nilai minimum & 45 & 20 \\
\hline Nilai rata-rata & 64,38 & 42,81 \\
\hline Jumlah sampel & 16 & 16 \\
\hline Standar deviasi & 9,81 & 13,41 \\
\hline
\end{tabular}




\section{c. Uji Prasyarat}

Hasil uji normalitas dengan menggunakan SPSS dapat dilihat pada tabel 3:

Table 3 Output Hasil Uji Normalitas

\begin{tabular}{|l|r|r|r|r|r|r|}
\hline \multicolumn{7}{|c|}{ Tests of Normality } \\
\hline & \multicolumn{3}{|c|}{$\begin{array}{c}\text { Kolmogorov- } \\
\text { Smirnova }\end{array}$} & \multicolumn{3}{|c|}{ Shapiro-Wilk } \\
\hline & Statistic & Df & Sig. & Statistic & Df & Sig. \\
\hline Hasil_Belajar & .107 & 32 & $.200^{*}$ & .965 & 32 & .377 \\
\hline Motivasi & .164 & 32 & .028 & .933 & 32 & .047 \\
\hline
\end{tabular}

a. Lilliefors Significance Correction

*. This is a lower bound of the true significance.

Berdasarkan tabel di atas nilai sig hasil belajar 0,377 > 0,05 artinya terdistribusi normal. Akan tetapi sig motivasi $0,047<0,05$ artinya data tidak terdistribusi normal. Karena salah satu data tidak terdistribusi normal maka uji hipotesis yang selanjutnya dilakukan adalah uji nonparametris yaitu kruskal wallis test dan man-whitney test. Adapun grafik distribusi frekuensinya bisa dilihat pada gambar 3 dan 4 . 


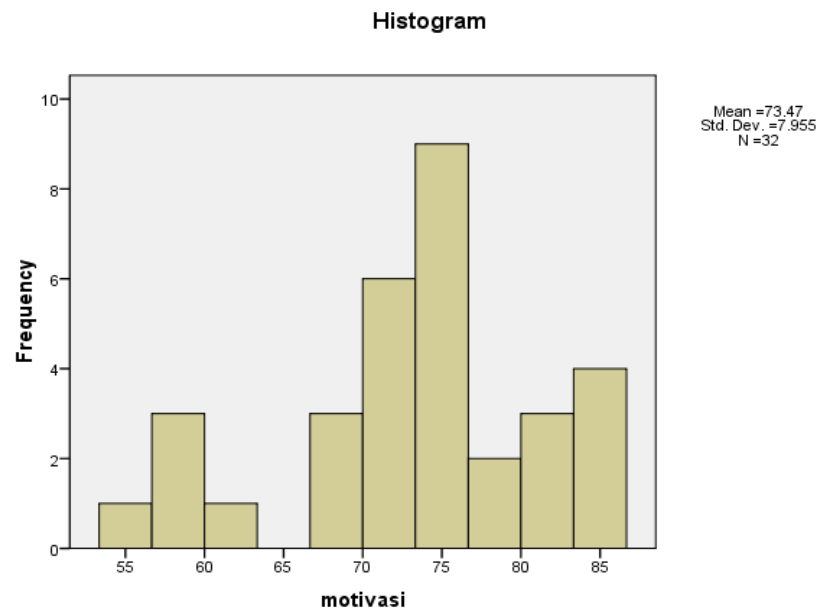

Gambar 1. Grafik distribusi frekuensi motivasi belajar

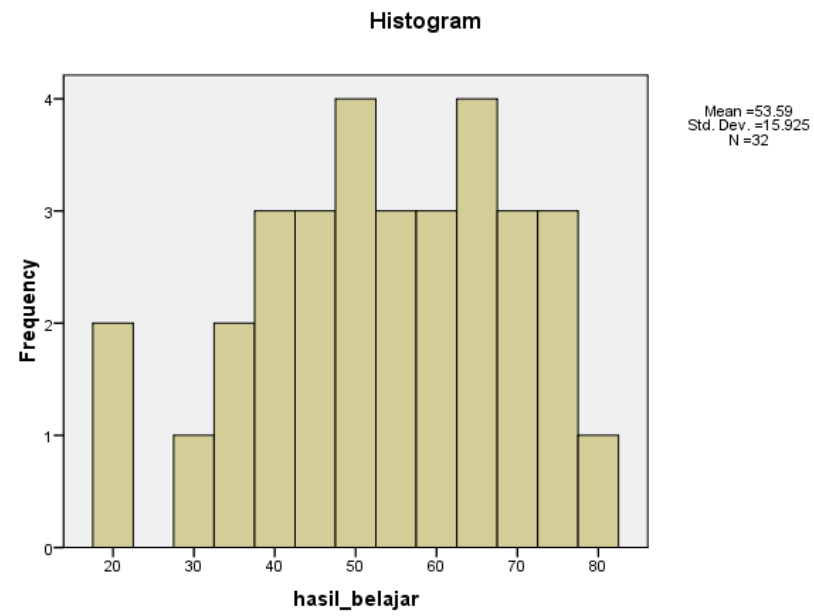

Gambar 2. Grafik distribusi frekuensi hasil belajar 


\section{PEMBAHASAN}

Berdasarkan hasil pengujian hipotesis secara multivariat, maka disimpulkan bahwa terdapat perbedaan yang signifikan antara motivasi dan hasil belajar kimia peserta didik yang diajar dengan model pembelajaran cooperative tipe pair checks dengan peserta didik yang diajar dengan model konvensioanal. Hal ini bisa dilihat dengan nilai sig yang diperoleh yaitu 0,001<0,05. Hipotesis yang kedua yaitu, terdapat perbedaan yang signifikasi motivasi belajar kimia peserta didik yang diajar dengan model pembelajaran cooperative tipe pair checks dengan peserta didik yang diajar dengan model konvensioanal yaitu $0,039<0,05$. Dan hipotesis yang ketiga yaitu, terdapat perbedaan yang signifikasi hasil belajar kimia peserta didik yang diajar dengan model pembelajaran cooperative tipe pair checks dengan peserta didik yang diajar dengan model konvensioanal yaitu 0,000 < 0,05. Deskripsi data motivasi menunjukkan bahwa jumlah nilai rata-rata pada kelas kontrol ialah sebesar 70,12 dan di kelas eksperimen berjumlah 76,81 . Selain itu, perbedaan hasil belajar kimia pada kelas eksperimen dan kelas kontrol juga dapat dilihat dari perbedaan nilai rata-rata pada deskripsi data hasil belajar, yaitu kelas kontrol berjumlah 42,8 dan kelas nilai eksperimen berjumlah 64,38.

Adapun kendala-kendala pelaksanaan penelitian pada kelas eksperimen dan kontrol yaitu jika ada siswa yang tidak hadir maka ada siswa yang tidak ada pasangannya, sehingga siswa tersebut bergantian dengan pasangan lain 
dalam satu kelompok. Kendala yang lain juga ialah manajemen waktu yang kurang maksimal, sehingga pelajaran baru bisa dimulai setelah 5-10 menit berlalu. Kemudian Pada kelas kontrol, beberapa siswa tidak memperhatikan guru yang menjelaskan materi di depan kelas dan sibuk sendiri.

Penggunaan model pembelajaran di kelas kontrol dengan menggunakan metode ceramah terlihat guru lebih mendominasi selama pelaksanaan proses pembelajaran di kelas. Siswa hanya duduk diam mendengarkan penjelasan guru sehingga kurang terjadi interaksi antar siswa dengan guru. Model pembelajaran ini tentunya tidak akan menimbulkan timbal balik baik antara siswa dengan guru maupun siswa dengan siswa yang lain, karena pada dasarnya pelaksanaan pembelajaran pada kelas kontrol hanya berpatokan kepada guru saja. Menurut Djamarah metode ceramah adalah metode yang dikatakan tradisional karena sejak dulu metode ini telah digunakan sebagai alat komunikasi lisan antara guru dengan anak didik dalam proses belajar dan mengajar (Djamarah, 2008). Pembelajaran dengan metode ceramah membuat siswa merasa tidak dilibatkan dalam pelaksanaan proses pembelajaran. Hal ini akan menimbulkan motivasi yang rendah bagi siswa. Hasil belajar sangat dipengaruhi oleh motivasi belajar.

Sementara itu penelitian yang dilakukan di kelas eksperimen menunjukkan siswa dituntut untuk saling berbagi kemampuan sehingga terjadi saling tukar pendapat 
dan melatih kemampuan berkomunikasi. Pada proses saling berbagi, terlihat siswa yang berkemampuan tinggi bisa saling berbagi sehingga siswa lain tidak sungkan bertanya dengan temannya yang lebih mengerti. Pada proses ini terjadi interaksi siswa yang menjadikan siswa lebih aktif dalam proses pembelajaran. Setiap siswa juga dituntut untuk memiliki tanggung jawab terhadap tugasnya masingmasing, karena tugas diberikan oleh guru berbeda-beda. Maka siswa dituntut untuk mempersiapkan diri (belajar) sebelum proses pembelajaran dimulai. Selain itu pada pembelajaran cooperative tipe pair checks yaitu pada saat pengecekan hasil pekerjaan dilakukan oleh masing-masing pasangan yang dilakukan secara bergiliran.

Pembelajaran cooperative mengajarakan siswa untuk saling menghargai satu sama lain dan mendorong komunikasi antar siswa sehingga hubungan antar siswa semakin baik. Pembelajaran cooperative juga dapat meningkatkan keterampilan sosial siswa yaitu mengajarkan kepada siswa keterampilan bekerja sama, saling membantu dan meningkatkan rasa percaya diri. Dalam model pembelajaran cooperative tipe pair checks guru bertindak sebagai motivator dan fasilitator aktivitas siswa. Model ini bertujuan untuk meningkatkan kemampuan siswa dalam menuangkan ide, pikiran, pengalaman, dan pendapatnya dengan benar. Dengan strategi pair checks memungkinkan siswa untuk saling memberikan saran (Kunandar, 2009).

Model pembelajaran pair checks merupakan model pembelajaran yang lebih menekankan pada kemandirian 
siswa dalam proses pembelajaran, sehingga setiap siswa dituntut untuk lebih menguasai materi yang telah diajarkan. Selain itu model pembelajaran pair check juga akan membuat siswa lebih aktif untuk menjawab persoalan yang diberikan melalui kerja kelompok sehingga kendala belajar siswa secara mandiri dan adanya siswa yang kurang aktif dalam proses pembelajaran dapat diminimalisir.

Hasil penelitian ini didukung oleh penelitian yang dilakukan oleh Fandi Ahmad (2016) yang menyatakan bahwa metode cooperative learning tipe pair checks berpengaruh positif terhadap motivasi dan hasil belajar siswa. Begitu juga dengan penelitian Islamiah, dkk (2016) serta Edy Setiyo Utomo dan Rahman Fatchiyah (2016) menunjukkan metode cooperative learning tipe pair checks berpengaruh positif terhadap hasil belajar siswa.

\section{KESIMPULAN}

Berdasarkan hasil penelitian dan pembahasan maka dapat ditarik beberapa kesimpulan sebagi berikut:

1. Hasil penelitian yang dilakukan secara multivariat menunjukkan bahwa terdapat pengaruh yang signifikan antara motivasi dan hasil belajar kimia peserta didik yang diajar dengan model pembelajaran cooperative tipe pair checks dengan peserta didik yang diajar dengan model konvensioanal yaitu 0,001<0,05.

2. Hasil penelitian pada variabel motivasi belajar, terdapat pengaruh yang signifikasi motivasi belajar kimia peserta didik yang diajar dengan model pembelajaran 
cooperative tipe pair checks dengan peserta didik yang diajar dengan model konvensioanal yaitu 0,039<0,05.

3. Hasil penelitian pada variabel hasil belajar juga terdapat pengaruh yang signifikasi hasil belajar kimia peserta didik yang diajar dengan model pembelajaran cooperative tipe pair checks dengan peserta didik yang diajar dengan model konvensioanal yaitu 0,000 <0,05.

\section{DAFTAR PUSTAKA}

Ahmad, Fandi. (2016) Penerapan Model Pembelajaran Kooperatife Tipe Pair Checks Dalam Meningkatkan Motivasi dan Hasil Belajar IPA Terpadu Siswa Kelas VIII A SMP Negeri 1 Tabulanan Kab. Mamasa. Jurnal Sanismat. Vol. V, Nomor 2, hlm. 137.

Djamarah, S. B., (2008) Psikologi Pendidikan. Jakarta: Rineka Cipta.

Huda, Miftahul. (2017) Model-Model Pengajaran dan Pembelajaran. Yogyakarta: Pustaka Pelajar.

Islamiah., Amin, B. D., \& Azis, A. (2016). Penerapan Model Pembelajaran Kooperatif Tipe Pair Checks Terhadap Hasil Belajar Peserta Didik di Kelas IX2 SMP Negeri 1 Balusu Kabupaten Barru. Jurnal Pendidikan Fisika. 4(2). hlm. 153.

Kunandar. (2009) Guru Profesional Implementasi Kurikulum Tingkat Satuan Pendidikan (KTSP) dan Sukses Dalam Sertifikasi Guru. Jakarta: PT. Raja Grafindo Persada. Utomo, E. S., dan Fatchiyah, R. (2016). Pengaruh Model Pembelajaran Kooperatif Tipe Pair Check Terhadap 
Hasil Belajar Siswa. Seminar Nasional Matematika dan Pendidikan Matematika UNY. 